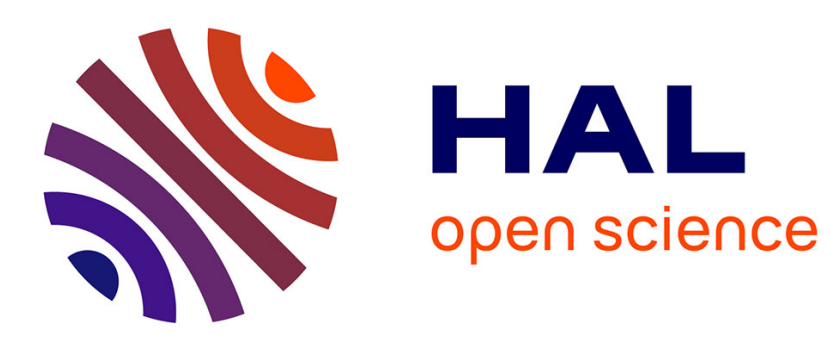

\title{
Islamic Financial Development Between Trend and Stability in the MENA region: Application on Panel Data
}

\author{
Abderraouf Mtiraoui
}

\section{To cite this version:}

Abderraouf Mtiraoui. Islamic Financial Development Between Trend and Stability in the MENA region: Application on Panel Data. Islamic Financial Development Between Trend and Stability in the MENA region: Application on Panel Data, 2019. hal-02494748

\author{
HAL Id: hal-02494748 \\ https://hal.science/hal-02494748
}

Submitted on 29 Feb 2020

HAL is a multi-disciplinary open access archive for the deposit and dissemination of scientific research documents, whether they are published or not. The documents may come from teaching and research institutions in France or abroad, or from public or private research centers.
L'archive ouverte pluridisciplinaire $\mathbf{H A L}$, est destinée au dépôt et à la diffusion de documents scientifiques de niveau recherche, publiés ou non, émanant des établissements d'enseignement et de recherche français ou étrangers, des laboratoires publics ou privés. 


\title{
Islamic Financial Development Between Trend and Stability in the MENA region: Application on Panel Data
}

\author{
Abderraouf Mtiraoui ${ }^{1}$ \\ E-mail: abderraouf100@yahoo.fr \\ University of Sousse- Tunisia \\ Research Laboratory : $L A M I D E D$
}

\begin{abstract}
Drawing on a review of the innovative literature, we first examine theoretically the nature of the relationship between financial development and economic growth, while taking into account the role played by Islamic finance in steering investment and public spending. which takes into account the effective human (education) in the presence of conventional finance. Finally, we try empirically to discover the influences of Islamic finance as a trend towards economic growth describing the stability and sustainability of any financial system used and hence the relationship between Islamic financial development and economic growth. Our empirical validation is based on a panel data application for our MENA region over a long period of 20 years (1990-2009).
\end{abstract}

Keywords: Islamic financial development, Economic growth, Panel data.

Classification JEL: G32, C13, C33.

\section{Introduction}

The interrelationship between financial development and economic growth highlights the conditions of the relationship between the financial and economic aspects and also the mechanisms through which finance influences economic growth. International Islamic financial activity is supported by large issues of Islamic securities such as Sukuk especially in UK in Europe as well as by North Africa in Africa in 2014. These types of emissions follow growth. has been maintained in the industry for a few years since Islamic finance grants the highest standards in ethics and stability during the international financial crisis.

Moreover, the emergence of the Sukuk market is likely to generate lasting structural changes in global financial markets, as it reflects the measures taken by a growing number of countries to integrate Islamic finance into their investment programs expenditures for economic and social development.

\footnotetext{
${ }^{1}$ Abderraouf Mtiraoui; Doctor in Economy and social science at the Higher Institute of Finance and Taxation of Sousse-Tunisia.
} 
Indeed, many contributions examine the link between the development of the financial system and economic growth, namely the studies of Levine \& Zervos (1998) and Beck \& Levine (2004) who tested the relationship between the development of the stock market, the development of banking sector and economic growth. In addition, the main results show that the banking development indicator does not correlate significantly with economic growth, while the indicator of stock market development is significantly correlated with growth. The MCO results result from a strong positive link between stock market development and economic growth and a strong positive relationship between banking development and growth.

In this context, the authors argue that the development of banks and stock exchanges has a positive impact on long-term economic growth. Mamun A., Basher S, Hoque N, and Ali M. (2018) examined the role of stock markets in the economic growth of four Asian countries, namely Bangladesh, India, and China. In the short term, they have noticed that stock markets also have a positive relationship with economic growth in all countries.

Finally, we will recall once again, first of all, that finance is a source of growth. Secondly, we will study the research methodology and finally, we will estimate and interpret the results found.

\section{Literature paper}

\section{The Dicourse of Islamic Finance}

The Board of Directors of the International Monetary Fund (IMF) granted in 2018 a proposal for the use of the Fundamental Principles for the Regulation of Islamic Finance (IFPCR) from the Islamic Financial Stability Board (IFSB) and developed with the participation the Secretariat of the Basel Committee on Banking Control (BCBS). These principals are intended to regulate and supervise the Islamic banking sector.

In this work, the literature will discuss the role of classical finance as a source of economic growth while taking into account the participation of Islamic banks that can not create credit like conventional banks and also that do not have an interbank market. Indeed, Islamic finance also seems to play a role in economic development through the mobilization of savings. Khan and Mirakhor (1994) complement this vision by showing that Islamic monetary policy operates in a setting where all the classical tools available in a modern economy are available to the monetary authorities, with the exception of the discount rate. and 
other tools that involve the use of interest. Moreover, the idea of sharing risks and returns, and materiality or a direct link between finance and the real economy, is at the center of Islamic finance. The above principles helped protect Islamic finance from exposure to reckless conduct and toxic assets that were at the heart of the global financial crisis. Islamic banks do not have the same attributes as conventional banks.

The central question how this Islamic financial system (the development of Islamic finance) as a trend contributes to the stability of economic growth even in the presence of conventional finance for the MENA region?

\section{Islamic finance model is a growth sector?}

Rapid growth and innovation is transforming the Islamic financial system while fostering economic development in a growing number of jurisdictions, based on the growing number of new financial opportunities such as Islamic finance. While the system is developing because it has experienced growth rates that were gradually increasing. This Islamic financial system leads to emergence in the global financial system.

According to Jaseem Ahmed (2014), "the values and ethics of Islamic finance constitute its social and moral capital. They contribute to the stability of Islamic finance, and its broader appeal. But they must be accompanied by other measures to promote stability and resilience, which also requires a sound financial infrastructure, in the form of legal and regulatory frameworks, and strong transparency and disclosure regimes that ensure that funding serves the real sector ${ }^{2 "}$.

In fact, the global financial crisis has led to a developed protection of the financial system to avoid financial imbalances. Thus, it is important to support the financial system through judicial regulations.

Moreover, the political and institutional aspects in a number of countries of which Islamic finance is well supported given the total evaluation its performance on a global scale. In addition, the Islamic financial system and its functioning contribute to global financial stability by diversifying the structure of economic and financial risk, but its own resistance faces considerable policy and regulatory testing.

\footnotetext{
2Jaseem Ahmed (2014), "Islamic Finance: A tendency too important to be ignored", Business Reporting. https: //www.ifac.org/ global-knowledge-gateway/business-reporting/ discussion / finance-Islamic-a-trend-too.
} 


\section{Recent Trends, Inquiries and Research Problem}

The existence of Islamic banks improves the field of activity which becomes varied in some countries, the financial sector is entirely Islamic (Iran and Sudan); in others, the two systems coexist (United Arab Emirates, etc.); and in still others, there are only one or two Islamic banks.

Indeed, the current trend seems to be towards the separation between the two types of banks. While some countries have chosen a net separation, others have allowed conventional banks to open Islamic windows, allowing some of the largest multinational institutions to participate. Even the big classic banks of the United States and Europe have opened Islamic financing windows. The debt market (foreign or domestic) is the most successful sector of Islamic finance.

- Does Islamic financial development have a significant impact on economic growth for our study area?

- Does Islamic Financial Development Promote Growth for MENA Countries?

\section{a. Islamic Ethical Finance: Another Financial Challenge?}

Among the obstacles of Islamic finance, we quote the unresolved monetary problems namely the problem of monetary creation and the absence of an interbank market.

Despite the potential for captive capital, the only risk in Islamic finance remains unanticipated. The potential for development remains largely under the influence of political will.

\section{b. Econometric methods}

* Ordinary least squares (OLS) model

The assumptions that make it possible to use the ordinary least squares (OLS) method have a disadvantage of endogeneity.

Given the particular nature of the panel data, this technique is biased, even if the estimators are consistent. ${ }^{3}$

\footnotetext{
${ }^{3}$ Mtiraoui, A. and Gabsi, F. (2019), "Finance between Islamic ethics and economic growth". Revue RAFI; Vol.3, $\mathrm{N}^{\circ} 1$, https://revues.imist.ma/index.php?journal=RAFI\&page=article\&op=view\&path\%5B $\% 5 \mathrm{D}=13030$.
} 
Unlike the ordinary least squares method, panel data is used to track an individual $\mathbf{i}$ (i $=\mathbf{1}$ to $\mathbf{N}$ ) over a period $\mathbf{T}(\mathbf{t}=\mathbf{1}$ to $\mathbf{T})$, which means that the data is doubly indexed.

We thus note in a general way:

$$
Y_{i, t}=\alpha+\gamma Z_{i, t}+\theta K_{i, t}+\delta X_{i, t}+\varepsilon_{i, t}
$$

This equation becomes:

$$
G D P_{i, t}=\alpha+\gamma \mathrm{IF}_{\mathrm{i}, \mathrm{t}}+\theta C F_{i, t}+\delta_{1} E d_{i, t}+\delta_{2} \operatorname{Inv} v_{i, t}+\delta_{3} \operatorname{Exp}_{i, t}+\delta_{4} \operatorname{Trad}_{i, t}+\delta_{5} D V_{i, t}+\varepsilon_{i, t}
$$

Avec $; \boldsymbol{Y}_{i, t}=\boldsymbol{G D P} \boldsymbol{P}_{i, t}$ (Indicator of Growth)

$Z_{i, t}=\mathrm{IF}_{\mathrm{i}, \mathrm{t}} \quad$ (Islamic Finance)

$\boldsymbol{K}_{\boldsymbol{i}, \boldsymbol{t}}=\mathbf{C F}_{\mathbf{i}, \mathrm{t}}($ conventionnel Finance $)$

$X_{i, t}=\left(E_{i, t}, \operatorname{Inv}_{i, t}, \operatorname{Exp}_{i, t}, \operatorname{Trad}_{i, t}\right.$ et $\left.D V_{i, t}\right)$ With; $D V_{i, t}=$ Dummy Variable $)$

$\boldsymbol{\varepsilon}_{\boldsymbol{i}, \boldsymbol{t}}=\boldsymbol{\alpha}_{\mathbf{i}}+\boldsymbol{\mu}_{\mathrm{i}, \mathrm{t}}$ où $\boldsymbol{\alpha}_{\mathrm{i}}$ et $\boldsymbol{\varepsilon}_{\boldsymbol{i}, \boldsymbol{t}}$ sont des perturbations aléatoires non corrélées. There are uncorrelated random disturbances. The estimation of the equation allows us to adopt a specification in terms of a composite error model.

* Description of the model

To empirically study the role played by financial development on economic growth, the following simple model is used:

$$
G D P_{i, t}=\alpha+\gamma I F_{i, t}+\theta C F_{i, t}+\lambda X_{i, t}+\varepsilon_{i, t}
$$

Cette fonction sera développée et elle devient: $\boldsymbol{G D P}_{\boldsymbol{i}, \boldsymbol{t}}=\alpha+\boldsymbol{\gamma} \boldsymbol{I F}_{\boldsymbol{i}, \boldsymbol{t}}++\boldsymbol{\theta} \boldsymbol{C} \boldsymbol{F}_{\boldsymbol{i}, \boldsymbol{t}}+$

$$
\delta_{1} \operatorname{Inv}_{i, t}+\delta_{2} \operatorname{Exp}_{i, t}+\delta_{3} E_{i, t}+\delta_{4} \operatorname{Trad}_{i, t}+\delta_{45} D V_{i, t}+\varepsilon_{i, t} \quad(\mathrm{E}-2)
$$

We have built a properly macroeconomic database and the IBIS database ${ }^{4}$.

\section{Méthodologie de recherche}

We introduce three types of variables in our model. First, the growth variable, which depends on the model. We then guide the indicators of financial development. Finally, we introduce a conditional information matrix to control variables that affect long-term economic growth.

\footnotetext{
${ }^{4}$ http://www.ibisonline.net/ le 18/12/2012
} 


\section{Sample and Period}

\section{a. Sample ${ }^{5}$}

Our sample consists of 16 countries namely Bahrain, United Arab Emirates, Jordan, Kuwait, Qatar, Saudi Arabia, Oman, Iraq, Morocco, Tunisia, Liby, Turkey, Egypt, Iran, Sudan, Yemen. We have built a database of the truly international macroeconomic data available in "World Bank $C D$ "

\section{b. Period}

Our study period is formed by a period of 20 years depending on the availability of existing data. The great diversity in terms of geography and in terms of country performance makes it possible to increase the robustness of our analyzes.

\section{Definitions and measures of variables}

\section{a. Growth indicator}

We chose the GDP growth rate per capita (Levine et al., 2000, Beck et al., 2000, and Beck and Levine, 2004).

\section{b. Financial Development Indicators}

We propose the following indicators.

$$
\text { * Depth }
$$

This variable is proposed by King and Levine (1993a, b). In this context, King and Levine (1993a, b), Levine et al. (2000), Kpodar (2005) admit a significant correlation between financial development and economic growth.

To measure the financial depth (Depth), King and Levine (1993a, b), Levine et al. (2000), Kpodar (2005) use the M3 aggregate corresponding to the liquid liabilities of the financial system divided by GDP. In our work, we use the M3 / GDP aggregate provided by the IBIS

\footnotetext{
${ }^{5}$ Rym Ayachi Ammar, Mehrez Ben Slama and Dhafer Saidane (2013), "Does the current practice of Islamic banks promote growth? ". Studies in Islamic Economics, Vol.6, No 1\&2,p.p. 12
} 
database for our sample of Islamic banks. This measure is an indicator of the development of Islamic finance and includes the liquid assets of the liabilities of Islamic banks.

\section{Islamic financing.}

In their 1998 study, Levine and Zervos add the measure of development of the banking sector to cross-sectional studies of growth. According to these authors, this measure is equal to the credit of the private sector divided by the GDP noted IF (Finis / GDP): Qard Hasan, Murabahah, Ijarah, Moudarabah, Moucharakah, Salam, Istisna '. ).

In addition, several authors such as Levine and Zervos (1998), Rousseau and Wachtel (2000), Beck and Levine (2004) show that the level of development of the banking sector, measured by credit activity, is significantly positive and correlates with the growth. In our work, we use the value of Islamic financing which is equal to the sum of the following operations:

\section{Investment}

Abu-Bader and Abu-Qarn (2008) include the investment-to-GDP ratio to determine whether financial development affects economic growth by improving efficiency or, indirectly, by increasing investment resources rated Inv (Invest / GDP).

In our work variable reflects the financial development measured not only by the retail activity but also by the banking activity.

\section{* Control Variables.}

For this work, we used the government expenditure-to-GDP (Exp) ratio as an indicator of macroeconomic stability (Easterly and Robelo (1993) and Fisher (1993)) as the control variables, the value ratio of trade ( exp. + imp.) / GDP to capture the degree of openness (Sachs and Warver (1995)) noted (Trad) and The tertiary enrollment rate to control the accumulation of human capital noted $(\mathbf{E d})$. 


\section{Mute variables}

We use this nature of variables (dummy variable: $\boldsymbol{D V}$ ) because our study area is formed by countries that apply Islamic finance and other more or month. So we score 1 for countries that practice Islamic finance and 0 for others.

\section{Empirical model}

In the specificity of the model, we used macroeconomic variables. We explain the nature of the effects of these variables on growth. We then use a model with a fixed or random effect to study the effects of variables on growth over a very well-defined period while updating the data used. While changing endogenous variables and exogenous variables.

\section{* Fixed effects model}

We assume that the assumption of constant individual effects is validated. We will determine the general form of the estimators of the parameters $\boldsymbol{\beta}_{\boldsymbol{i}}$ and $\boldsymbol{\varphi}^{\prime}$ in this fixed-effect model.

$$
Y_{i, t}=\beta_{i}+\varphi^{\prime} X_{t}+\varepsilon_{i, t} ; \quad \text { For all } \mathbf{i} \epsilon[1 ; \mathrm{N}] ; \text { For all } \mathbf{t} \epsilon[1 ; \mathrm{T}]
$$

All the parameters of the model are constants and it is supposed to simplify that there is no temporal effect. To study the properties of the fixed effects model estimators, we will make an additional hypothesis on the nature of the residue process $\boldsymbol{\varepsilon}_{\boldsymbol{i}, \boldsymbol{t}}$; This assumption is simply the generalization in the $\mathrm{p}$ anel dimension of the definition of a white noise.

\section{* Random effects model}

In the standard practice of econometric analysis, it is assumed that there are a large number of factors that can affect the value of the explained variable and that are not explicitly introduced as explanatory variables. Indeed, these factors are then approximated by the structure of the residues. The problem arises in a similar way in panel econometrics. The only difference is that three types of omitted factors can be considered. First, there are the factors that affect the endogenous variable differently depending on the period and the individual considered. 
In addition, there may be factors that affect all individuals identically, but whose influence depends on the period considered (temporal effects). With; $\boldsymbol{\varepsilon}_{\boldsymbol{i}, \boldsymbol{t}}=\boldsymbol{\theta}_{\boldsymbol{i}} \zeta_{\boldsymbol{t}, \boldsymbol{i}}+\boldsymbol{\mu}_{\boldsymbol{i}}$; For all i $\epsilon[1 ; \mathbf{N}]$; For all $\mathrm{t} \epsilon[1 ; \mathbf{T}]$

\section{Estimates, interpretations and conclusions}

\section{Descriptive analysis}

\section{a. Descriptive statistics}

Table 1: Descriptive statistics of variables

\begin{tabular}{|l|l|l|l|l|l|}
\hline \multicolumn{1}{|c|}{ Variables } & \multicolumn{1}{|c|}{ Obs. } & \multicolumn{1}{|c|}{ Mean. } & \multicolumn{1}{c|}{ Std. Dev. } & \multicolumn{1}{c|}{ Min. } & Max. \\
\hline GDP & 320 & 4.79819 & 4.861579 & -10.04967 & 33.99047 \\
\hline CF & 320 & 8.045258 & 46.59423 & 0.0000383 & 540.1351 \\
\hline Inv & 320 & 1.271845 & 5.012045 & -6.462162 & 24.01051 \\
\hline IF & 320 & 0.1149592 & 0.6755422 & 0.0000177 & 11.98022 \\
\hline GC & 320 & 0.5677975 & 0.1441396 & 0.1666667 & 0.8733797 \\
\hline Ed & 320 & 1.110093 & 0.3253679 & 0.0002012 & 1.663964 \\
\hline Trade & 320 & -0.2142848 & 1.27513 & -4.670521 & 1.740128 \\
\hline DV & 320 & 0.8125 & 0.3909237 & 0 & 1 \\
\hline
\end{tabular}

Source: the output of Stat15 made by the author 
Table1 : Matrix of correlations between the variables

\begin{tabular}{|l|l|l|l|l|l|l|l|l|}
\hline Variables & GDP & CF & INV & IF & GC & Ed & Trade & DV \\
\hline GDP & 1.0000 & & & & & & & \\
\hline CF & -0.1101 & 1.0000 & & & & & & \\
\hline INV & 0.0837 & 0.6848 & 1.0000 & & & & & \\
\hline IF & -0.0282 & 0.0294 & -0.0604 & 1.0000 & & & & \\
\hline GC & 0.0919 & -0.0682 & -0.0978 & -0.1328 & 1.0000 & & & \\
\hline Ed & 0.0747 & 0.0219 & 0.0598 & 0.0255 & -0.0747 & 1.0000 & & \\
\hline Trade & 0.1471 & -0.0091 & -0.0143 & -0.2016 & 0.6362 & 0.1338 & 1.0000 & \\
\hline DV & 0.0463 & 0.0741 & 0.1174 & 0.0600 & -0.0025 & -0.1823 & -0.2423 & 1.0000 \\
\hline
\end{tabular}

Source: the output of Stat15 made by the author

From the table of correlation matrices, we note that there is a strong positive correlation (greater than $\mathbf{0 . 5}$ ) between conventional finance $(\mathbf{C F})$ and the ratio of investment to GDP (Inv / GDP) (0.6848).

In addition, there is a weak negative relationship between education and the dummy variable (D.V) (-0.2423). 


\section{Simple Regression}

Table 2: Simple Regression of Finance on Economic Growth

\begin{tabular}{|c|c|c|c|c|c|c|}
\hline $\begin{array}{r}\text { Number of ol } \\
\text { R-squared }\end{array}$ & $\begin{aligned} \mathbf{S} & =320 \\
& =0.485\end{aligned}$ & $\begin{array}{l}7,312)=5 \\
\text { dj R-squared }\end{array}$ & $\begin{array}{r}\text { Prob }> \\
.272\end{array}$ & $=0.00$ & & \\
\hline GDP & Coef. & Std. Err. & $\mathbf{t}$ & $P>|t|$ & [95\% Conf. & nterval] \\
\hline CF & -0.0017897 & 0.0079514 & $(-3.25)^{* * *}$ & 0.0213 & 0.0255769 & .0057134 \\
\hline Inv & -0.0357183 & 0.0749202 & -0.48 & 0.634 & -0.183131 & 0.1116944 \\
\hline IF & -0.0802814 & 0.0749202 & $(-1.96)^{*}$ & 0.044 & -0.183131 & 0.1116944 \\
\hline GC & -0.9371529 & 2.530136 & -0.37 & 0.711 & -5.91544 & .041134 \\
\hline Ed. & 1.102354 & .8611983 & 1.28 & 0.201 & -0.5921367 & 2.796845 \\
\hline Trade & 0.6888273 & .2970493 & $(2.32)^{* * *}$ & 0.021 & 0.1043542 & 1.2733 \\
\hline DV & 1.430727 & 0.7367556 & $(1.94)^{*}$ & 0.053 & -0.018911 & 2.880365 \\
\hline Cst. & 3.220107 & 1.958773 & 1.64 & 0.101 & -0.6339677 & 7.074181 \\
\hline
\end{tabular}

Source: the output of Stat15 made by the author

The results in this table indicate that the growth indicator (GDP) and the financial development indicators (IF and CF) are two negative coefficients respectively (-0.00099) and $(-0.03)$, so the share of these two variables is not explanatory since the effects on the growth indicator (GDP) are negative.

The equation, in this case, is written as follows:

$$
\begin{array}{r}
\boldsymbol{G D P}_{i, t}=3.2201-0.001783 \boldsymbol{C F}_{i, t}-0.035 \operatorname{Inv}_{i, t}-0.937 G C_{i, t} \\
-0.08028 \mathrm{IF}_{\mathrm{i}, \mathrm{t}}+1.430 \mathrm{DV}_{\mathrm{i}, \mathrm{t}}+0.688 \boldsymbol{T r a d}+\varepsilon_{\mathrm{i}, \mathrm{t}}
\end{array}
$$

The explanatory power $\left(\mathbf{R}^{2}\right)$ is less than $\mathbf{0 . 4 8}$ of which $\left(\mathbf{R}\right.$-Squared $\left.=\mathbf{R}^{\mathbf{2}}=\mathbf{0 . 2 1 7 5}\right)$. This explains the residual power formed by other variables can be among the variables of the equation. 


\section{Estimates, interpretations and comments}

\section{a. Estimates}

Table 3: Regressions by four estimation methods

\begin{tabular}{|c|c|c|}
\hline Vb7es & Equation $\mathrm{N}^{\circ} 1$ & Equation $\mathrm{N}^{\circ} 2$ \\
\hline Cste & $\begin{array}{c}2.66 e-15 \\
(0.62)\end{array}$ & $\begin{array}{c}-7.94 e-15 \\
(-0.66)\end{array}$ \\
\hline CF & $\begin{array}{l}-1.60 e-17 \\
(-\mathbf{3 . 3 4}) \star \star \star\end{array}$ & $\begin{array}{c}-4.66 e-18 \\
(-0.87)\end{array}$ \\
\hline Inv & $\begin{array}{l}3.71 e-16 \\
(4.68) * \star \star\end{array}$ & $\begin{array}{c}8.15 e-17 \\
(0.92)\end{array}$ \\
\hline IF & $\begin{array}{c}-8.33 e-17 \\
(-1.93) \star\end{array}$ & $\begin{array}{l}3.41 e-16 \\
(2.01) * *\end{array}$ \\
\hline GC & $\begin{array}{c}-5.01 e-15 \\
(-1.93) *\end{array}$ & $\begin{array}{c}1.36 e-15 \\
(0.47)\end{array}$ \\
\hline Ed & $\begin{array}{c}1.39 e-17 \\
(0.01)\end{array}$ & $\begin{array}{l}-1.02 e-14 \\
(-6.26) * \star \star\end{array}$ \\
\hline Trade & $\begin{array}{l}4.22 e-14 \\
(\mathbf{2} .83) * \star \star\end{array}$ & $\begin{array}{l}3.88 e-15 \\
(2.45) * \star *\end{array}$ \\
\hline DV & ------ & $\begin{array}{c}1.83 e-14 \\
(1.45)\end{array}$ \\
\hline N.obs. & 320 & 320 \\
\hline F. & 12.000 & ---- \\
\hline \multicolumn{3}{|l|}{ T.Wald } \\
\hline Sargan-T $\chi^{2}()$ & ----- & ----- \\
\hline Prob >chi2 & 0.00010 & 0.00000 \\
\hline
\end{tabular}

Source: the output of Stat 15 made by the author

Equation $\mathrm{N}^{\circ} 1$ : We use the fixed effects method.

Equation $\mathbf{N}^{\circ} 2$ : We use the random effects method.

*** Significant at 1\%, ${ }^{* *}$ Significant at 5\%, ${ }^{*}$ Significant at10 \%. 


\section{b. Interpretations}

Table 5 presents the results obtained, while estimating the growth model based on four estimation methods namely the fixed effects method, the random effects method for our Middle East and North Africa region MENA.

\section{$>$ The fixed effects method}

The results of Equation 1 show that Islamic finance (IF) has a negative (-8.33e-17) and a $10 \%$ significant effect on growth (GDP) so for conventional finance (CF) is negatively significant $1 \%$ for MENA countries.

Indeed, an increase in IF (Finis / GDP) to $\mathbf{1 0 \%}$ introduces an 8-points decrease in economic growth, whereas a $\mathbf{1 \%}$ increase in CF (Depth) hinders economic growth (GDP) with a drop of $\mathbf{1 . 6 .}$

In addition, the indicators (Inv) and (Trade) have two positive and significant effects on economic growth, which favors the idea of a growth engine. Almost an increase in (Inv / GDP) and (UO) at $\mathbf{1 \%}$ introduces a successive rise of (screen) of $\mathbf{4}$ and 5 points.

In this context of estimation and apart from the indicators (Inv / GDP) and (Trade) that collaborates most empirical studies, the IF and $\mathbf{C F}$ do not validate the hypothesis that Islamic finance plays an important role as a catalyst of growth in the sense of Schumpeter recently.

\section{$>$ The random effects method}

The results of Equation $\mathrm{N}^{\circ} 2$ show that Islamic finance (IF) has a positive effect (3.4) and a significant 5\% on growth (GDP) so for conventional finance CF is negatively insignificant for Middle East countries and North African MENA. In fact, an increase of IF to 5\% introduces a 3.4 points increase in economic growth. Also, the indicator of commercial openness (Trad) is significantly positive in relation to the indicator of growth (GDP) which approves the review of the existing literature.

Moreover, some studies consider that Islamic finance can have an effect on improving financial development and accelerating growth (Chapra, 1993, Kazarian, 1993).

In addition, Islamic finance also appears to play a role in economic development through the mobilization of savings (Zaher and Hassan, 2001). Khan and Mirakhor (1994) complement this vision by showing that Islamic monetary policy takes place in a framework where all the classical tools. 


\section{c. Comments}

We performed four different regressions according to the method adopted to interpret the correct result.

Indeed, empirical checks on the link between Islamic financial development and macroeconomic growth are very limited in the sense of these authors namely: Abduh and Omar (2012), Abduh and Chowdhury (2012), Furqani and Mulyany (2009) and Majid and Kassim (2010). In addition, the unavailability of data in Islamic finance for most Middle Eastern countries does not help to clarify the important role of finance in general as a catalyst for economic growth.

Despite these shortcomings of the data, there are empirical studies and attempts that show the weight of finance to the economic circuit and in this sense other works consider above all Islamic finance as playing an important role in the fight against social exclusion and improving well-being (Bremer, 2004 and Ebrahim, 2009). Surely, beyond their role in providing social services, Islamic charities have served as redistributive mechanisms to reduce gaps and inequalities by providing aid to the poor. These organizations offer the opportunity to the rich to be in solidarity with the poor. They recognize their obligations to help and fight against poverty its causes and effects (Bremer, 2004 and Ebrahim, 2009).

This type of work examines the link between financial development (financial sphere) on economic growth (real sphere) during small periods of five years, so our contribution on the one hand clarifies this relationship for twenty successive years (long period) and for countries from different continents (golf country, North Africa country, Asian country).

\section{Conclusion}

In our study, we examined the role of Islamic finance from the banking system that describes the financial development of nations and promotes economic growth for many authors.

Indeed, for our MENA study region which consisted of 16 countries, over 20 periods from 1990 to 2009 , we estimated by four different methods namely the fixed effects model (this type of work exists in the journal empirical) and the random effect model (there are not many such contributions and econometric inputs). 
In our estimation, the three variables measuring the development of Islamic finance (Depth, Inv / GDP and IF / GDP) are statistically significant. The depth of Islamic finance (Depth) measured by the ratio M3 / GDP has a negative sign. This reflects the fact that this financial deepening, measured by the increase in money supply in the presence of an unfavorable environment can not be effective.

Also, Islamic financing (IF) and Investment (Inv / GDP) have a positive sign. These two indicators have a positive impact on economic growth. In Equation $\mathrm{N}^{\circ} 2$ which validates the hypothesis that Islamic finance plays, for the moment, an important role as a growth engine in the literal sense of the literature.

In addition, the effect of this bank credit on the growth indicator of MENA countries shows Islamic banks are limited effects on growth may be a consequence of the non-maturity of the Islamic financial system.

Zaher and Hassan (2001) also show that size is one of the major challenges that Islamic banks will have to face in the coming years in order to better assert their competitiveness. This weakness in size does not favor the economies of nations. In addition, ethical finance remains important compared to conventional finance especially in this economic reality.

There is also the question of monetary creation which remains embryonic in academic work. This last aspect of macro-monetary nature is undoubtedly one of the points to be clarified through further studies.

\section{Bibliographic}

- Abduh, M. et Omar, M. Azmi. (2012), «Islamic banking and economic growth: the Indonesian experience », International Journal of Islamic and Middle Eastern Finance and Management, Vol. 5, No. 1, pp. 35-47.

- Abu-Bader S. et Abu-Qarn A. S.(2008), «Financial Development and Economic Growth: Empirical Evidence from Six MENA Countries», Review of Development Economics, 12(4), 803-817, 2008.

- Arellano et Bonde (1991), "Some Tests of Specification for Panel Data: Monte Carlo Evidence and an Application to Employment Equations". The Review of Economic Studies, Volume 58, Issue 2.

- Arellano et Bover (1995), “Another look at the instrumental-variable estimation of errorcomponents models", Journal of Econometrics 68, 29-52. 
- Beck T. et Levine R. (2004), «Stock markets, Banks, and Growth: Panel Evidence. », Journal of Banking \& Finance, Volume 28, Issue 3, March, pp: 423-442

- Boualem Bendjilali (1992), "Introduction aux techniques islamiques de financement »,

Edition Institut Islamique de Recherches et de Formation, Banque Islamique de Développement, Acte de séminaire $\mathrm{N}^{\circ} 37, \mathrm{p} .32-55$.

- Bremer, J. (2004) «Islamic Philanthropy: Reviving Traditional Forms for Building Social Justice », Paper submitted at the 5th Annual Conference.

- Chatti M.A. (2010), «Analyse comparative entre la finance islamique et le capitalrisque », Etudes en économie islamique Vol.4, $\mathrm{N}^{\circ} .1$.

- Ebrahim, M.S. (2009), « Can an Islamic model of housing finance cooperative elevate the economic status of the underprivileged? », Journal of Economic Behavior \& Organization 72, pp. 864-883.

- El Qorchi Mohammed (2005), «La finance islamique est en marche », Finances \& Développement.

- Hasan Z. (2008): "Credit creation and control: an unresolved issue in Islamic banking », International Journal of Islamic and Middle Eastern Finance and Management, vol 1 (1), pages 69-81.

- Martens André (2001), «La finance islamique : Fondements, théorie et réalité », Cahier 20- 2001, Centre de recherche et développement en économique (C.R.D.E.) et Département de sciences économiques, Université de Montréal.

- Iqbal, M. et Khan, M. F. (1981), « A Survey of Issues and a Programme for Research in Monetary and Fiscal Economics of Islam », International Centre for Research in Islamic Economics.

- King R.G. et Levine R.(1993b), «Finance, Entrepreneurship, and Growth: Theory and Evidence. »Journal of Monetary Economics, December, Vol. 32 (3), pp. 513-42.

- Kpodar K.R. (2005), «Le Développement Financier et la Croissance : L'Afrique Subsaharienne est-elle Marginalisée ? », African Development Review, Volume 17 Issue 1, pp. 106-137

- Levine, R., N. Loayza et T. Beck (2000), «Financial Intermediation and Growth: Causality and Causes », Journal of Monetary Economics, 46: 31-77.

- Majid, S.A. et Kassim, S. (2010), "Islamic finance and economic growth: The Malaysian experience”, In: Kuala Lumpur Islamic Finance Forum, Kuala Lumpur, 2-5 August 20. 
- Mtiraoui Abderraouf et Gabsi Feriel (2019), « La finance entre l'éthique islamique et la croissance économique ». Revue RAFI; Vol.3, $\mathrm{N}^{\circ} 1$. https://revues.imist.ma/index.php?journal=RAFI\&page=article\&op=view\&path\%5B $\% 5 \mathrm{D}$ $=13030 \&$ path $\% 5 B \% 5 \mathrm{D}=8668$.

- Saffari, S. (1995), "Islamic banking in theory and practice », Centre of Middle Eastern Studies working paper, Havard University.

- Uzair, M.(1978), « Central Banking Operations in an Interest-Free Banking System », in Mohammad Ariff (ed.), Monetary and Fiscal Economics of Islam, pp. 211-235.

- Zaher, T. S. et Hassan M. K. (2001), « A Comparative Literature Survey Of Islamic Finance And Banking », Financial Markets, Institutions \& Instruments, V. 10, No. 4, pp: 155-195 